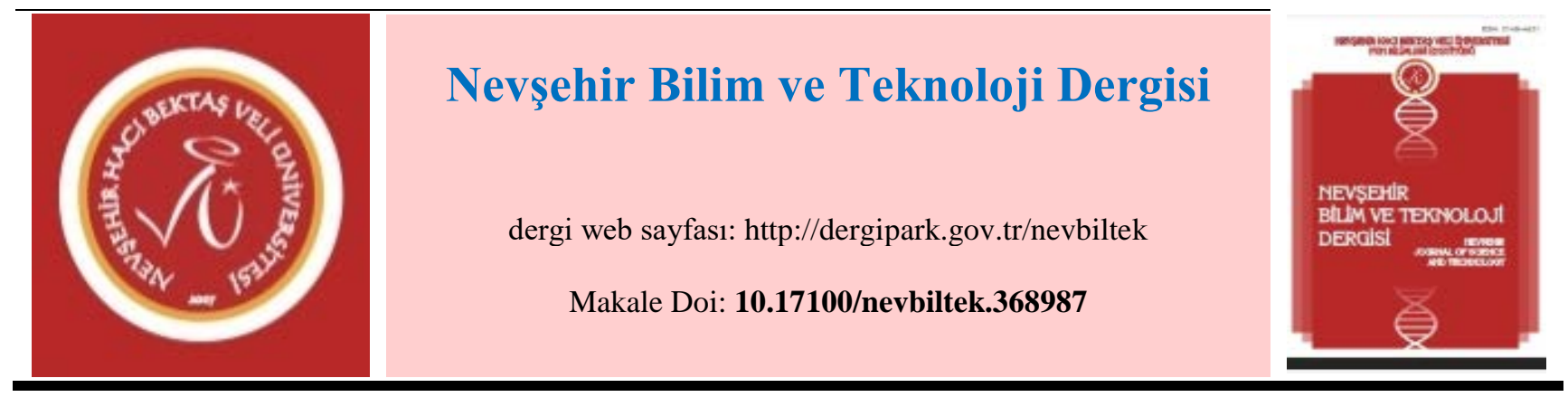

\title{
Effect of Different Metal Oxides on Vickers Hardness of the Frit Based Crystalline Glazes
}

\author{
Keriman PEKKAN ${ }^{1 *}$, Yalçın GÜN² \\ ${ }^{1}$ Dumlupinar University, Faculty of Fine Arts, Department of Ceramic and Glass, \\ Kütahya, Türkiye \\ ORCID ID: 0000-0002-2153-9940
}

${ }^{2}$ Dumlupinar University, Graduate School of Natural and Applied Science, Master of Science in Materials Science and Engineering, Kütahya, Türkiye

ORCID ID: 0000-0002-4855-6134

\begin{abstract}
Frit based glaze is a thin glassy surface coating which gives technical and aesthetic value to the ceramic product after firing. Crystalline glazes are one of the most important type of artistic glazes formed through a controlled crystallization of glass during a special heat treatment. Crystals are visible to the naked eye and the product can have only a few single crystals on the surface or the entire surface can be coated with crystals. The preferred clay substrate for crystalline glazes is porcelain and in some cases may be used for the macrocrystallines. Usage of these types of glazes as porcelain tile coatings is an alternative choice for relevant ceramic industry and these glazes strongly enhance the visual quality of the final products. When designing crystalline glazes for porcelain tiles; besides the chemical composition, mechanical properties such as hardness is also an important factor. Within the scope of experimental studies, frit based crystalline glazes which consist of different nucleating agents such as $\mathrm{MnO}, \mathrm{Fe}_{2} \mathrm{O}_{3}, \mathrm{NiO} \mathrm{CoO}$, $\mathrm{CuO}$ and $\mathrm{Cr}_{2} \mathrm{O}_{3}$ were applied on the raw porcelain bodies and then subjected to a special heat treatment cycle. The aim of this study was to investigate the effect of different metal oxides on crystallization capacity of newly developed fritted glaze compositions and Vickers hardness of the final products. Micro hardness of the glazes was measured with Vickers hardness test method. Characterization of crystalline glazes was done by x-ray diffraction (XRD) technique.
\end{abstract}

Keywords: Hardness, crystallization, metal oxides

\footnotetext{
${ }^{1}$ Some part of the study was presented in $2^{\text {nd }}$ International Conference on Materials Science and Technology IMSTEC 2017 in Cappadocia, Nevsehir, Turkey, October 2017 and the copyright for such parts belongs to IMSTEC.

Corresponding Author e-mail: keriman.pekkan@dpu.edu.tr
} 


\section{Nevşehir Bilim ve Teknoloji Dergisi (2018), 7(1) 32-40}

\section{Introduction}

There are many types of glazes in the ceramic industry and the demand for new products is increasing each passing day. Ceramic glazes can be classified as raw or fritted depending on their composition or method of production or, by making a generalization that can cover all of these groups, as liquid or viscous liquid. They can also be classified as single-firing and double-firing glazes or according to the different firing atmospheres [1-2]. There are glazes with various colours and surface properties currently being used. The physical and mechanical properties of the final product is related to some factors such as firing procedure, temperature, application method, and its ingredients. Therefore, in order to develop and calculate a new glaze, it is necessary to control the whole production process and know the behaviour and effect of its component materials [3].

The knowledge of ceramic glaze occurrence can lead to develop glazes with appropriate physical, chemical and mechanical properties to fulfil particular requirements according to application areas. Glazes provide hardness, chemical resistance and protection against external effects to the materials they coat. When designing a new product for ceramic market by using crystalline glazes, the final appearance is not the only factor because the glaze should also fulfil the desired mechanical properties. Hardness is one of the most important mechanical properties of ceramic glazes and microhardness is defined as the resistance offered by the materials against breaking. Conventionally, the measurements in the hardness test are performed using a Vickers indenter. The Vickers hardness test is performed by exerting a force of $1 \mathrm{~kg}(9.81 \mathrm{~N})$ for a specific period of time [4-6].

An artistic type of glaze, the crystal glazes are glazes that contain crystals which enlarge while cooling, along with the firing process [7]. Nowadays, crystalline glazed products exhibit many innovations for the decoration of ceramics. With crystal glazes, very diverse visual effects such as transparent, opaque, glossy or nacreous effects may be achieved on the glaze surface thanks to the micro and macro crystals dispersing within the glaze during the firing process. These glazes may be prepared as raw or fritted glazes. If the glaze does not contain soluble materials, it can be prepared as a raw glaze and cost effective glazes can be obtain. However, fritted glazes are more advantageous because they mature shortly with respect to raw ones [8-9].

Various factors play a role in the crystallization within the glaze. The most prominent of these factors is the fact that the liquidity of the glaze can be as high as possible, i.e. the viscosity is low [2]. As the components in a glaze with high viscosity are unable to move easily, a uniform structure (crystallization) is not created and vitreous solidification occurs [10]. The most convenient firing for the formation of crystal glazes is the oxidation firing [9, 11-12].

One of the most important factors for crystal glazes is the firing regime. Firing program not only determines the structure, but also determines the quantity of crystals that are reformed [13]. While forming these types of glazes, the temperature at which crystal cores (the smallest formation units) are created and at which the crystallization speed is the highest must be determined [14]. The size and growth of crystals are belong to firing regime and holding at the crystal growth temperature too much results in larger crystals [9]. Nucleating agents of crystalline glazes such as $\mathrm{MnO}_{2} \mathrm{Fe}_{2} \mathrm{O}_{3}$, $\mathrm{NiO}, \mathrm{CoO}, \mathrm{CuO}$ and $\mathrm{Cr}_{2} \mathrm{O}_{3}$ can be classified as additives and these are strong colorants in ceramic glazes. Color is produced by the absorption of particular wavelengths. The absorption spectra of transition metal ions and rare earth ions dissolved in glassy matrix gives rise to the understanding of the structure. Besides the coloring property, these metal oxides have an effect on crystal growth temperature. This temperature can change for each glaze according to the 
colorants because they may act as fluxes in glaze composition [13].

If the amount of certain oxides is sufficient in the glaze composition, crystallization occurs during cooling. The crystals of each material have different shapes and different growth speeds. While crystals in the shape of stripes, which are sometimes diagonal or which overlap each other, are formed with Zinc oxide ( $\mathrm{ZnO}$ ), crystals in the form of bunches that shine under the sunlight are obtained with rutile $\left(\mathrm{TiO}_{2}\right)$ [2,9,14-15]. In this study, the degree to which the metal oxides added as colorants affect the hardness of the crystal glaze is examined.

\section{Material and Method}

In this study, a new crystal glaze composition is developed by taking the crystal glazes [16-17] obtained from previous researches as the reference (Table 1). 100 grams of crystal glaze frits was weighed, loaded on the porcelain glaze mills containing carboxymethylcellulose (CMC) and sodium tripolyphosphate (STPP) addition as well as alumina balls. Then, the mixture is subjected to wet grinding for 50 minutes (Table 2). New recipes were developed by adding different percentages of $\mathrm{MnO}, \mathrm{Fe}_{2} \mathrm{O}_{3}, \mathrm{NiO}, \mathrm{CoO}, \mathrm{CuO}$ and $\mathrm{Cr}_{2} \mathrm{O}_{3}$ metal oxides to this glaze, which is coded as $\mathrm{R} 1$. Prepared glazes are applied on raw porcelain structures with the pouring method. Amount of metal oxides added to the glaze compositions are given in Table 3 and firing regime for glazed porcelain structures are depicted in Table 4. Glazes were characterized via PANALYTICAL-EMPYREAN model x-ray diffractometer (XRD) method with Cu Ka radiation and the scanning velocity of $2 \%$ min. The microhardness of crystals formed was measured by the device model DUROLINE-M of METKON. Hardness values were obtained for 15 seconds from different points of the crystal glaze samples fired using Vickers hardness testing method by using a load of $1 \mathrm{~kg}$. For each sample, the measurements are obtained from the crystal and the area without crystals. Three measurements were obtained from each area and the averages for these measurements were calculated.

Table 1. Composition ranges of the frit used in the studies

\begin{tabular}{ccccccc|c}
\hline $\mathrm{K}_{2} \mathrm{O}_{2} \mathrm{Al}_{2} \mathrm{O}_{3} .6 \mathrm{SiO}_{2}$ & $\mathrm{Na}_{2} \mathrm{CO}_{3}$ & $\mathrm{Li}_{2} \mathrm{CO}_{3}$ & $\mathrm{CaMg}\left(\mathrm{CO}_{3}\right)_{2}$ & $\mathrm{CaCO}_{3}$ & $\mathrm{ZnO}$ & $\mathrm{SiO}_{2}$ & $\mathrm{TiO}_{2}$ \\
\hline $20-25$ & $4-6$ & $1-3$ & $1-3$ & $3-12$ & $20-25$ & $35-40$ & $2-5$ \\
\hline
\end{tabular}

Table 2. Glaze composition (wt\%)

\begin{tabular}{lc}
\hline Material & Weight (\%) \\
\hline & 95 \\
\hline & 5 \\
\hline Carboxymethylcellulose (CMC) & 50 \\
\hline n tripolyphosphate (STPP) & 0.15 \\
\hline
\end{tabular}

Table 3. Amount of metal oxides added to the glaze compositions (wt\%)

\begin{tabular}{ccccccc}
\hline $\mathrm{R} 1$ & $\mathrm{R} 2$ & $\mathrm{R} 3$ & $\mathrm{R} 4$ & $\mathrm{R} 5$ & $\mathrm{R} 6$ & $\mathrm{R} 7$ \\
\hline- & $3 \mathrm{wt} \% \mathrm{Cr}_{2} \mathrm{O}_{3}$ & $3 \mathrm{wt} \% \mathrm{CuO}$ & $3 \mathrm{wt} \% \mathrm{MnO}$ & $3 \mathrm{wt} \% \mathrm{Fe}_{2} \mathrm{O}_{3}$ & $3 \mathrm{wt} \% \mathrm{CoO}$ & $0.03 \mathrm{wt} \% \mathrm{NiO}$ \\
\hline
\end{tabular}


Nevşehir Bilim ve Teknoloji Dergisi (2018), 7(1) 32-40

Table 4. Firing regime for glazed porcelain structures*

\begin{tabular}{llll}
\hline $\begin{array}{l}\text { Glaze firing temperature } \\
\left({ }^{\circ} \mathrm{C}\right)\end{array}$ & Waiting period (min.) & $\begin{array}{l}\text { Crystal formation temperature } \\
\left({ }^{\circ} \mathrm{C}\right)\end{array}$ & $\begin{array}{l}\text { Waiting period } \\
\text { (hour) }\end{array}$ \\
\hline 1295 & 5 & 1175 & 1 \\
\hline
\end{tabular}

*Heating speed $3{ }^{\circ} \mathrm{C} / \mathrm{min}$ and cooling speed $2{ }^{\circ} \mathrm{C} / \mathrm{min}$.

\section{Results}

Photos of the samples were taken after the firing and their surface properties were examined. Crystal glazes in different colours and shapes were obtained after the firing of glazes prepared by adding metal oxide (Figure 1). Vickers hardness values of the samples are shown in Table 5 and the comparison of the hardness values of glassy and crystal phases schematically are depicted in Figure 2. When the hardness measurements results were examined, it was determined that the glaze containing $\mathrm{MnO}$ metal oxide, coded R4, had the highest Vickers microhardness value. However, $\mathrm{CuO}$ is decreased the hardness value of the glaze. Other recipes with a high hardness value are R7, R6, R5, R2, R1 and R3, respectively. Accordance to XRD results, all of the glazes contain willemite crystals predominantly (Figure 3).

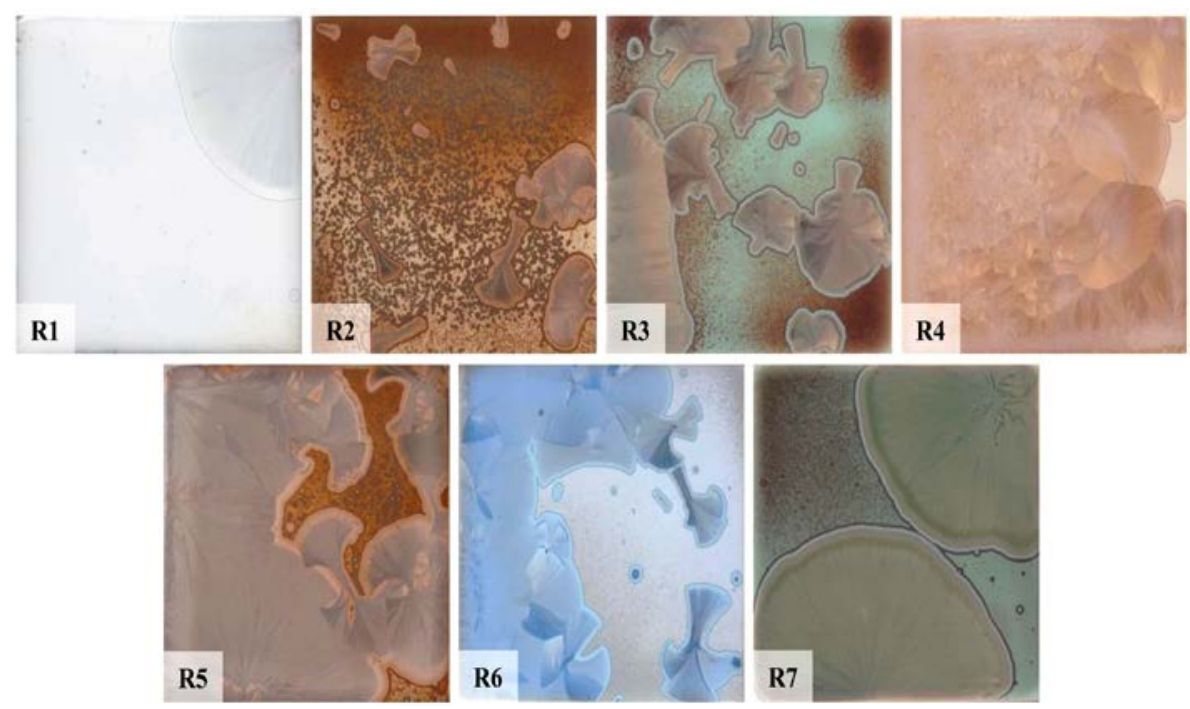

Figure 1. Surface images of samples fired with glazes.

Table 5. Hardness values of the samples.

\begin{tabular}{ccc}
\hline Recipes & $\begin{array}{c}\text { Glassy Phase } \\
\text { Hardness (MPa) }\end{array}$ & $\begin{array}{c}\text { Crystal } \\
\text { Hardness (MPa) }\end{array}$ \\
\hline R1 & 5070 & 6522 \\
R2 & 5649 & 6894 \\
R3 & 5247 & 5806 \\
R4 & 6198 & 8630 \\
R5 & 5816 & 7130 \\
R6 & 5649 & 7336 \\
R7 & 5335 & 8012 \\
\hline
\end{tabular}




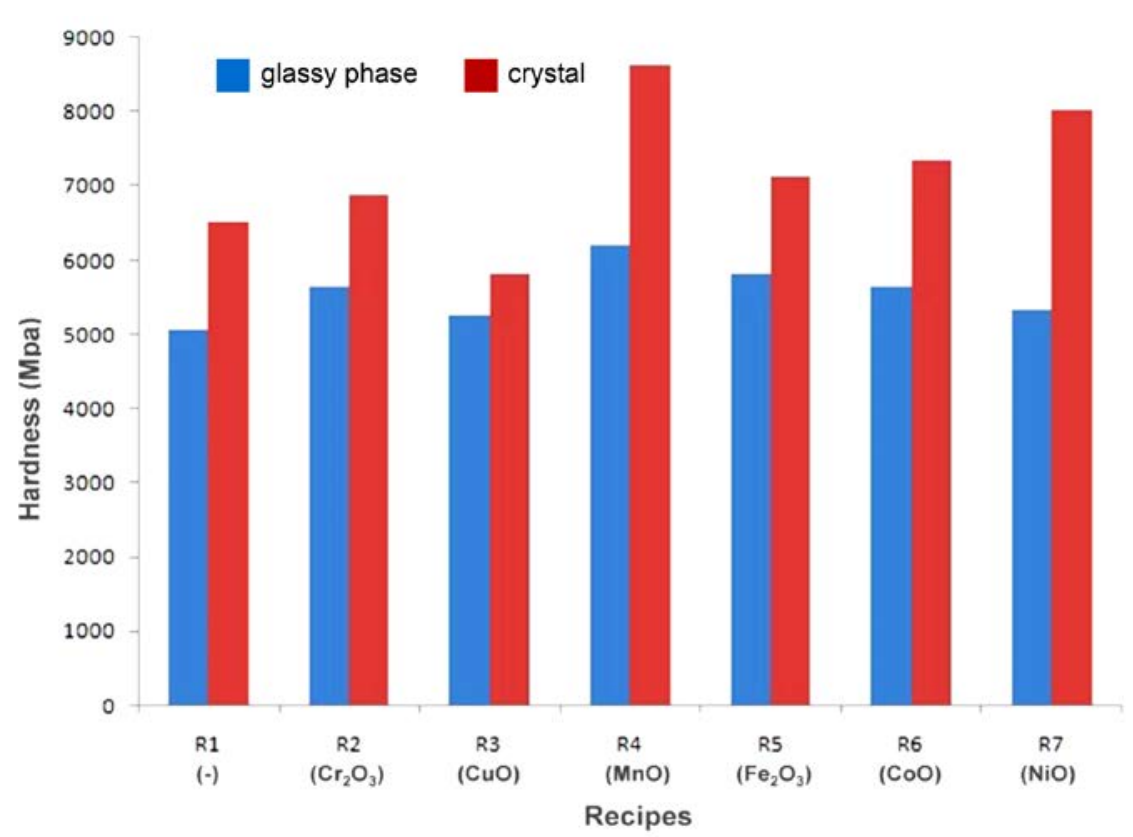

Figure 2. Comparison of the hardness values of glassy and crystal phases.

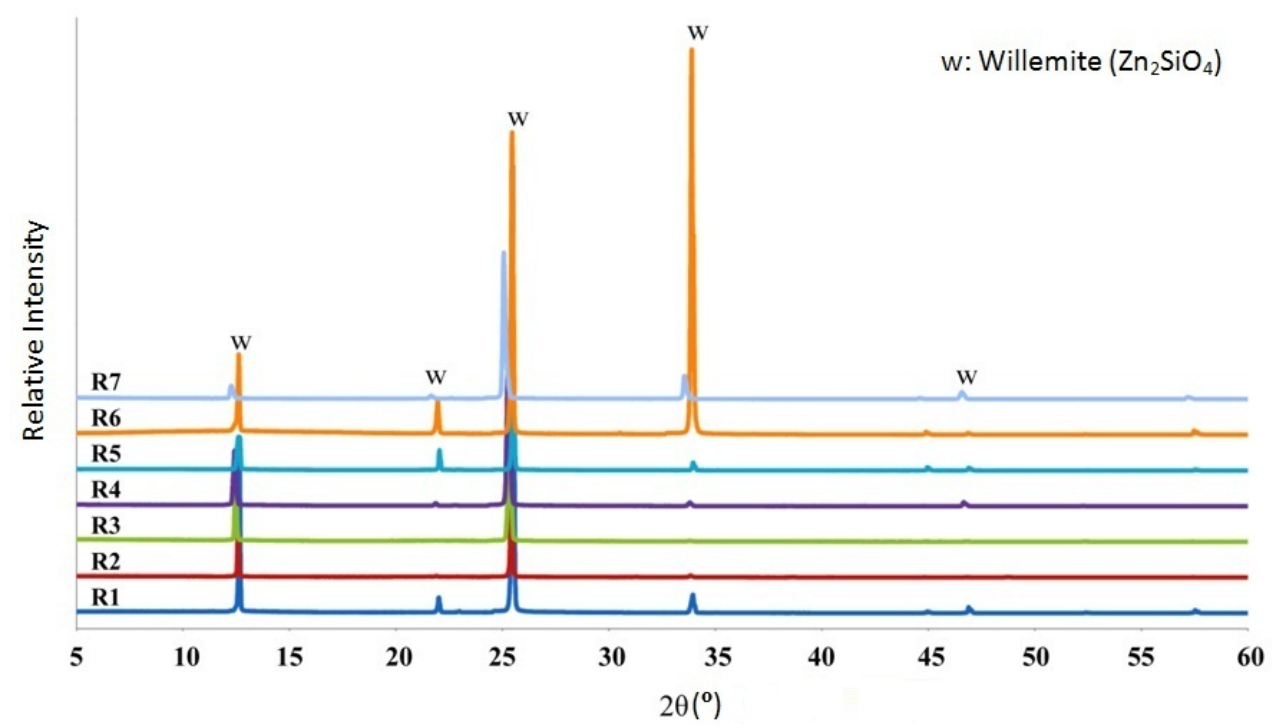

Figure 3. XRD patterns of the studied glazes.

\section{Discussion and Conclusion}

When the hardness values obtained from the glaze and crystal for each sample are examined, it is observed that the crystal formation increases the hardness of the glaze. Glaze R1, to which no metal oxide was added has the lowest hardness value. R 6 glaze which consist of 3 wt\% CoO, exhibited a relatively high peak intensity of willemite crystal. $\mathrm{CoO}$ is a strong colorant and gives shades of blue in glaze system [11]. Besides its powerfull colourant effect, $\mathrm{CoO}$ increased the peak intensity of willemite crystals amongst the other colorant metal oxides in the studied glaze compositions. A distinctive amount of zinc containing frit systems generally tend to form large macro crystalline zinc 
Nevşehir Bilim ve Teknoloji Dergisi (2018), 7(1) 32-40

silicate (willemite) $\mathrm{ZZnOSiO}_{2}$ [18-19]. Small crystals in the glaze structure give rise to whiteness and opacity, where as willemite grow in a transparent, residual transparent, and amorphous phase with a nakedly visible macro size.

The chemical and mechanical conditions of the glass surface directly influence the nucleation. The growth process of the willemite crystal is generally related to the firing procedure, chemical composition of the glaze, and the nucleating agents. The crystal formation is provided by $\mathrm{ZnO}$ and $\mathrm{SiO}_{2}$ affects the growth process of the glassy phase crystals [2021]. Generally in glaze systems, nucleating agents may lead to homogeneous or heterogeneous crystal nucleation according to amount and type of the agent. In some cases, these nucleating agents start the heterogeneous nucleation on the surface of the glassy phase so the kinetics of crystal nucleation and growth are key factors [9]. In order to control the willemite crystals, it is necessary to control the diffusion speed of silicon and zinc from the starting centre until the end of the acicular willemite crystal in which it grows. In this way, the growth rate of the willemite crystals in the spherical areas can be determined. It is necessary to conduct a special firing regime and apply a slow firing for zinc containing frit based macro crystal glazes. This results from the fact that crystallization in such systems requires a slower process, especially compared to other fast firing glazes [9,20,22].

To conclude, the metal oxide contribution into the glaze recipe increased the hardness values of the glazes generally. Moreover, the Vickers hardness values of the willemite crystals depicted higher degrees with respect to the glassy phases. $\mathrm{MnO}$ increased the hardness of the glaze much higher than $\mathrm{Fe}_{2} \mathrm{O}_{3}, \mathrm{NiO}, \mathrm{CoO}, \mathrm{Cr}_{2} \mathrm{O}_{3}$. However, it is observed that the hardness value of crystals in the $\mathrm{R} 3$ glaze, which is prepared by adding $\mathrm{CuO}$ is lower compared to the hardness of crystals in glaze colorant oxide free $\mathrm{R} 1$ and other glazes prepared by adding metal oxides $\left(\mathrm{MnO}, \mathrm{Fe}_{2} \mathrm{O}_{3}, \mathrm{NiO}, \mathrm{CoO}\right.$, $\left.\mathrm{Cr}_{2} \mathrm{O}_{3}\right)$.

\section{Acknowledgements}

We would like to thank Dumlupınar University and the employees of Dumlupınar University Advanced Technologies Center (ILTEM) for their support in the realization of this study. 


\section{References}

[1]Şölenay, E., "Seramik Sanat Eğitiminde Sırlama ve Pişirme Yöntemleri El Kitabı” Murat Kitapevi, Ankara, 2012.

[2]Arcasoy, A., “Ceramics Technology” Marmara Üniversitesi Güzel Sanatlar Fakültesi Seramik Ana Sanat Dalı Yayınları, İstanbul, 1983.

[3]Chavarrıa, J., “Ceramic Class: Glazing Techniques” Watson-Guptill Publishing, 1998.

[4]Quinn, G.D., "Hardness Testing of Ceramics” Advanced Materials \& Processes, 1998.

[5]Parmelee, C. W., Harman, C. G., “Ceramic glazes” CBI Publishing, Boston, MA, 1973.

[6]ASTM, ASTM C., 1327-03, "Standard Test Method for Vickers Indentation Hardness of Advanced Ceramics” ASTM-International, Metals Park, OH, 2003.

[7] McColm, I.J., “Dictionary of Ceramic Science and Engineering” Plenum Press, New York, 1994.

[8]Karasu, B., Çakı, M., Turan, S., “The Development and Characterization of Zinc Crystal Glazes. Used for Amakusa-like Soft Porcelains” Journal of the European Ceramic Society, 20(12), 2225-2231, 2000.

[9]Pekkan, K., "The Thermal and Microstructural behavior of a $\mathrm{R}_{2} \mathrm{O}-\mathrm{RO}-(\mathrm{ZnO})-\mathrm{Al}_{2} \mathrm{O}_{3}-\left(\mathrm{TiO}_{2}\right)-\mathrm{SiO}_{2} \mathrm{Based}$ Macro-Crystalline Raw Glaze System” Ceramics International, 41(6), 7881-7889, 2015.

[10]Kartal, A., "Sır ve Sırlama Tekniği” Çizgi Matbaacllık, Ankara, 1998.

[11]Karasu, B., Turan, S., "Effects of Cobalt, Copper, Manganese and Titanium Oxide Additions on the Microstructures of Zinc Containing Soft Porcelain Glazes” Journal of the European Ceramic Society, 22(9), 1447-1455, 2002.

[12]Pekkan, K., Taş̧ı, E, Gün, Y., "The Effect of ZnO on Development of Crystals in Crystal Glaze Applications” Journal of the Faculty of Engineering and Architecture of Gazi University, 30(2), 2015.

[13]Taylor, J.R., Bull, A.C., “Ceramics Glaze Technology” Oxford, Pergamon Books Inc.,Elmsford, NY, United States, 1986.

[14]Göncü, Y., "Investigation of the Usage of Wastes Containing $\mathrm{ZnO}$ in Crystal Glazes” Anadolu University, Graduate School of Sciences, Master of Science Thesis, Ceramic Engineering Program, Eskişehir, 2006.

[15]Gozalbo, A., Orts, M.J., Mestre, S., Gómez, P., Agut, P., Lucas, F., Blanco, C., "Ceramic Glazes With Aventurine Effect” In Qualicer 2006. IX World Congress on Ceramic Tile Quality, Castellon, Spain, Vol. 2, 189-202, 2006.

[16]Pekkan, K., Gün, Y., Taşçı, E., Gülaçt1, N., “Large Individual Crystals For Floor Tile Bodies” International Porous Powder Materials Symposium and Exhibition, İzmir, Türkiye, 450-455, 2015.

[17]Pekkan, K., Taşçı, E., Gülaçtı, E., Ürersoy, Y., Gün, Y., Ateş, H.A., "The Evaluatıon of Frit Based Artistic Crystalline Glaze Systems Using as Industrial Floor Tile Glazes” Scientific Research Project, Project Final Report, 2014-48. 2014.

[18]Rudkovskaya, N.V., "Mikhailenko, N.Y., Decorative Zinc-Containing Crystalline Glazes for Ornamental Ceramics (A Review)” Glass and Ceramics, 58(11), 387-390, 2001.

[19]Escardino, A., Amoros, J.L., Gozalbo, A., Orts, M.J., Moreno, A., "Gahnite devitrification in ceramic frits: mechanism and process kinetics” Journal of American Ceramic Society, 83(12), 2938-2944, 2000.

[20]Lewis, M.H., "Glasses and Glass Ceramics” Chapman and Hall, New York, 1989.

[21]Mirhadi, B., Mehdikhani, B., "Crystallization behavior and microstructure of $\left(\mathrm{CaO} \cdot \mathrm{ZrO}_{2} \cdot \mathrm{SiO}_{2}\right)-\mathrm{Cr}_{2} \mathrm{O}_{3}$-based glasses” Journal of Non-Crystalline Solids, 357(22), 3711-3716, 2011.

[22]Kingery, W.D., Bowen, H.K., Uhlmann, D.R., “Introduction to Ceramics” John Wiley and Sons, New York, 1976. 


\section{Genişletilmiş Özet}

Giriş: Firit esaslı sırlar pişirim sonrası seramik ürüne teknik ve estetik değer katan ince ve camsı yüzey kaplamalarıdır. Kristal sırlar özel bir ısıl işlem çerçevesinde camın kontrollü kristalizasyonu ile oluşan en önemli artistik sır çeşitlerinden biridir. Kristal sırlar cam fazı içerisinde veya yüzeyinde mikro veya makro kristaller ihtiva eden özel bir sır grubudur. Başlangıçtaki sır bileşiminde kristalleşmeyi sağlayıcı elemanlar içeren sır, belirli ve özel bir pişirim rejimi sayesinde olgunlaştıktan sonra yavaş yavaş soğuyarak kristalleşir. Bekleme sıcaklığına ve süresine bağlı olarak oluşan kristaller çıplak gözel görülebilir bir boyuta ulaşabilir. Reçete bileşimine ve kontrollü kristalizasyona bağlı olarak bazen ürün yüzeyinde sadece bir kaç tek kristal olabileceği gibi tüm yüzey kristallerle de kaplanabilir. Kristal sırlar için tercih edilen altlık tercihen porselen bünyedir. Bu tarz sırların porselen karo kaplamasında kullanımı, ilgili seramik endüstrisi için alternatif bir seçenek oluşturmaktadır ve bu sırlar nihai ürünlerin görsel kalitesini son derece etkilemektedir. Porselen karo için bir sır kompozisyonu tasarımı yapılırken; kimyasal kompozisyonun yanı sıra sertlik gibi mekaniksel özellikler de önemli bir etken olmaktadır. Kristal sırlarda çekirdekleştirici ajan olarak kullanılan $\mathrm{MnO} \mathrm{Fe}_{2} \mathrm{O}_{3}, \mathrm{NiO}$, $\mathrm{CoO}, \mathrm{CuO}$ ve $\mathrm{Cr}_{2} \mathrm{O}_{3}$ gibi renklendirici metal oksitler, nihai sırın renk özelliklerini belirlemenin yanında akışkanlaştırıcı özellikleriyle sırın viskozitesini de değiştirerek kontrollü kristalizasyondaki kristal büyüme sıcaklığını etkilerler. Bu araştırmanın amacı, çekirdekleştirici ajan olarak kullanılan farklı metal oksitlerin yeni geliştirilen firit esaslı sır kompozisyonlarının kristalizasyon kapasitesine ve nihai ürünlerin Vickers sertliklerine olan etkisinin araştırılmasıdır.

Yöntem: Bu çalışmada $\mathrm{MnO}, \mathrm{Fe}_{2} \mathrm{O}_{3}, \mathrm{NiO}, \mathrm{CoO}, \mathrm{CuO}$ ve $\mathrm{Cr}_{2} \mathrm{O}_{3}$ gibi farklı çekirdeklendirici ajanlar içeren firit esaslı kristal sırlar ham porselen bünyeler üzerine uygulandıktan sonra özel bir pişirim rejimine tabi tutulmuşlardır. Sırların mikro sertlik değerleri Vickers sertlik test yöntemiyle ölçülmüştür. Kristal sır yüzeylerinin karakterizasyonu x-1şını kırınımı (XRD) tekniği ile yapılmıştır. Sonuçlar ve Tartışma: Genel olarak sır bileşimine bağlı olarak yüksek oranda çinko oksit içeren sırlarda villemit $\left(2 \mathrm{ZnO} . \mathrm{SiO}_{2}\right)$ kristalizasyonu gerçekleşmiştir. Sırdan ve kristalden alınan sertlik değerleri incelendiğinde, kristal oluşumunun sertliği arttırdığı tespit edilmiştir. Hiç bir metal oksit ilavesi yapılmayan R 1 kodlu sırdaki camsı faz, en düşük sertlik değerine sahiptir. Sertlik ölçümlerine göre, MnO içeren R 4 kodlu sırdaki kristalin en yüksek Vickers mikrosertlik değerine (8630MPa) sahip olduğu belirlenmiştir. Ancak, bakır oksit ilavesi sırlardaki kristallerin sertliğini düşürmektedir. Ağırlıkça \% 3 oranında kobalt oksit (CoO) içeren R 6 sırı, diğer metal oksit içeren sırlara kıyasla göreceli olarak daha yüksek pik şiddetine sahip olan villemit kristali piki sergilemiştir. Güçlü renk verme kapasitesine sahip olan kobalt oksit mavi renkli kristal sır oluşumuna sebep olmasının yanı sıra villemit oluşumuna da katkıda bulunmuştur. Cam yüzeyinin kimyasal ve mekanik durumu çekirdeklenmeyi doğrudan etkilemektedir. Villemitin oluşum prosesi genel olarak pişirim sürecine bağlıdır. Sır sistemlerinde, çekirdekleştirici ajan olarak kullanılan metal oksit ilaveleri çeşidine ve miktarına bağlı olarak homojen veya heterojen kristalizasyona yol 
Nevşehir Bilim ve Teknoloji Dergisi (2018), 7(1) 32-40

açabilir. Bazı durumlarda, çekirdeklendirici ajan, camsı fazın yüzeyinde heterojen çekirdeklenmeyi başlatabilir ve bu nedenle, sır üretiminde kristal çekirdeklenme ve büyüme kinetikleri oldukça önemli ve etkin parametrelerdir. Villemit kristalizasyonunun kontrolü için, silisyum ve çinkonun difüzyon hızlarının başlangıç merkezinden büyüyen çubuksu villemit kristallerinin sonuna kadar kontrol edilmesi önem arz etmektedir. Diğer kristal sır çeşitlerine kıyasla makro kristalizasyon için daha yavaş bir prosese ihtiyaç duyulmaktadır. Bu nedenle, özellikle hızlı pişirimdeki sırlardan farklı olarak daha özel bir sır bileşimine, çekirdeklendirici ajan kontrolüne ve pişirim rejimine gereksinim vardır. Sonuç olarak bu çalışmada, sır reçetesine ilave edilen $\mathrm{MnO}, \mathrm{Fe}_{2} \mathrm{O}_{3}, \mathrm{NiO}, \mathrm{CoO}$ ve $\mathrm{Cr}_{2} \mathrm{O}_{3}$ gibi metal oksitler genel olarak sırın sertliğini artırmıştır. Sertlik derecesindeki artış bu çekirdeklendirici oksitlerin türüne göre değişiklik göstermiştir. MnO; $\mathrm{Fe}_{2} \mathrm{O}_{3}, \mathrm{NiO}, \mathrm{CoO}, \mathrm{CuO}$ ve $\mathrm{Cr}_{2} \mathrm{O}_{3}{ }^{\prime}$ e kıyasla sertlik değerini en yüksek oranda artırmıştır. $\mathrm{CuO}$ ilavesiyle hazırlanan $\mathrm{R} 3$ sırında ise kristalin sertlik değerinin, metal oksit içermeyen $\mathrm{R} 1$ kodlu sır ve diğer oksitleri içeren $\left(\mathrm{MnO}, \mathrm{Fe}_{2} \mathrm{O}_{3}, \mathrm{NiO}\right.$, CoO ve $\mathrm{Cr}_{2} \mathrm{O}_{3}$ ) R 2, R 4, R 6 ve R 7 kodlu sırlara kıyasla azaldığı tespit edilmiştir. 